\title{
Data Warehouse Design Academic Affairs Case Study: Campus II STMIK STIKOM Bali Jimbaran
}

\author{
Putu Bagus Hendrayana Surya ${ }^{[1]}$, Rifky Lana Rahardian ${ }^{[2]}$, and Komang oka Saputra[3] \\ [1][2] Department of Electrical and Computer Engineering, Post Graduate Program, Udayana University \\ [3] Department of Electrical and Computer Engineering, Udayana University \\ E-Mail: ags.hendrayana@gmail.com
}

\begin{abstract}
At the management level, the information becomes a factor in the decision making process. It takes a form of support for different data processing of transactional data processing form that allows the leadership of obtaining accurate information and in a short time, so that will give birth to independence in obtaining information. Information on the student data needed by a coordinator academic campus to see the conditions in which academic information only from a centralized database in BAAK. To overcome these problems need to design a data warehouse for the system dashboard for campus coordinator can monitor academic conditions.
\end{abstract}

\section{Preliminary}

information systems can be used to obtain the data, process data into information and spread information on the results of data processing that previously to support strategic decision-making activities. Obstacles are often encountered is the fact that the system information has not been integrated perfectly and result in less accurate information.

STIKOM Bali Jimbaran Campus II is headed by a coordinator of the campus is still receiving reports manually on academic activities. Campus coordinator so difficult to make decisions and policies if there is an academic-related problems. Academic data only parentcentered campus located in Renon.

Data warehouse development is one way and solution to extract critical information from data spread across multiple information systems. Data is already integrated can then be used for the delivery of information that can be viewed from various dimensions and adjustable levels of details.

The data in the data warehouse can be used as input for the application system to be built. With the dashboard is expected to be a solution for the campus coordinator for monitoring academic condition and then can take the right decision if impaired student or things related to job performance lecturers.

\section{LITERATURE REVIEW}

\section{A. DATA WAREHOUSE}

According to Inmonin Imhoff, Galemmo and Geiger (2003) Data Warehouse set of data on the subject-oriented, integrated, has a range of time and can not easily change that is used to support strategic decision making. According Silvers (2008), there are seven characteristics of a data warehouse, namely: Enterprise Data, Subject Orientation, Data Integration. NonVolatity, Time Variant, One Version Of The Truth, Long-Term Investment.

a. Component Data Warehouse

To meet the needs of organizations arrangement of the components to be arranged in a certain way to get the maximum benefit, this can be done with a special emphasis on providing support to a component or other components.

b. Dimensional Model Data Warehouse

According to Silvers (2008) there are two concepts in data warehouse data model, namely:

1. Fact

Fact is known as an event or transaction. A fact is something that happens. A fact table combines the entities identified in the logical data modeling.

2. Dimensions

Dimensions are data describing qualifications of corporate entities involved in the facts.

The relationship between the fact and dimension tables and can be described with a dimensional schema, the schema data warehouse is the most commonly used is the star schema (Star Schema), which consists of a fact table surrounded by dimension tables.

\section{B. IRADAH}

IRADAH (Integrated Requirements Analysis for Designing Data Warehouse) is a technique developed by 
Munawar et.al (2011) to integrate data quality throughout the development phase of the data warehouse. The main objective of this method to answer the need to integrate data quality into the needs analysis phase, conceptual, logical and physical. Besides, with this can also combine this technical data owned by the company, the expected goals of the company's Data Warehouse development and how the harmonization with the users of the data warehouse. More details of these methods can be seen in Figure 1.

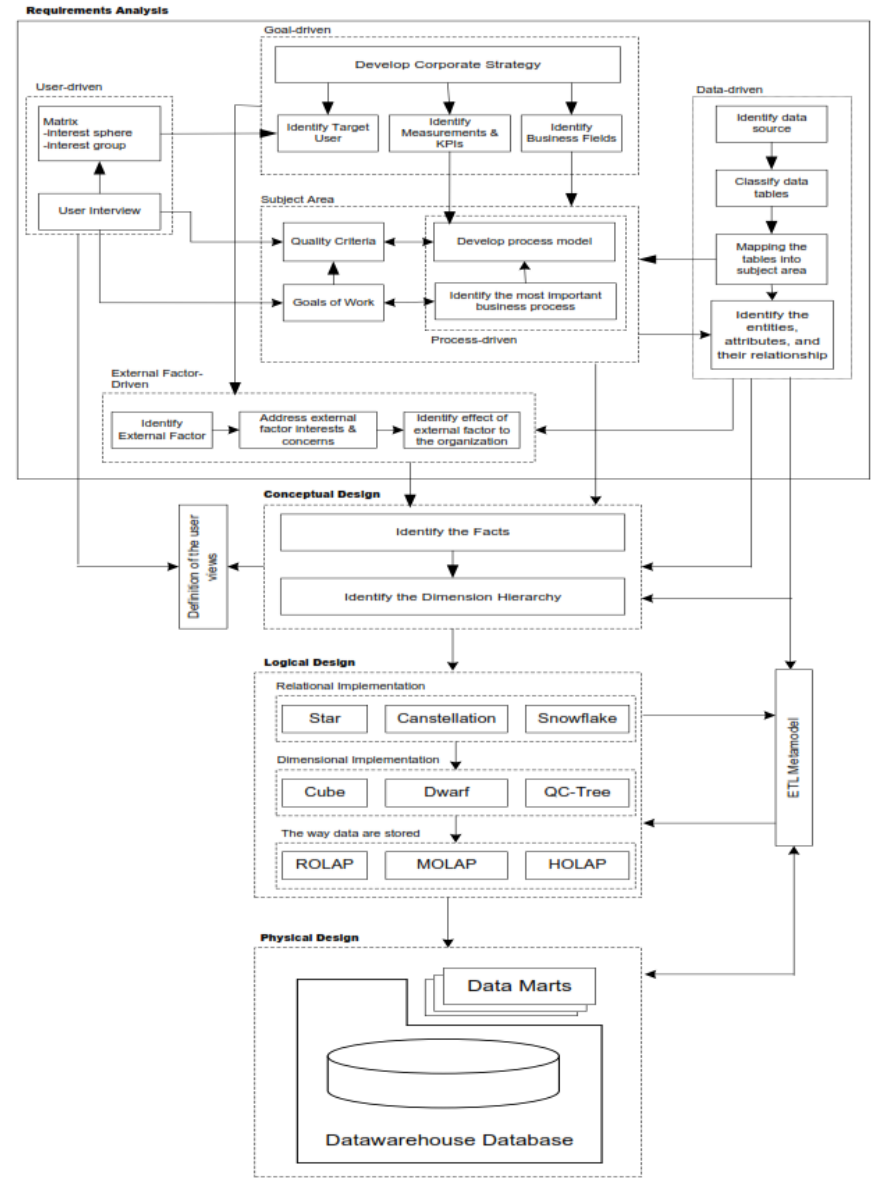

Figure 1: Architecture Method IRADAH

III.

DISCUSSION

\section{A. DATA WAREHOUSE DESIGN}

The design phase includes planning data sources, data warehouse architecture design and analysis of the data warehouse system requirements.

\section{Data Source}

The data source for data warehouse academic from several applications, among others:

- Source Data on Academic Information
Systems (to facilitate the user in the process of monitoring ongoing lectures and evaluating courses that has been accomplished).

- Source of Data in Information Systems Online (containing all the data of students, faculty and staff, as well as all transaction data, in this case is data lectures.

\section{Design Data Warehouse}

design phase of the second phase should be done for the establishment of a data warehouse. In it includes architectural design logical as well as physically from the data warehouse. Selection of the data contained in the data source in the form of applications that already exist.

A. Architecture Logical Data warehouse

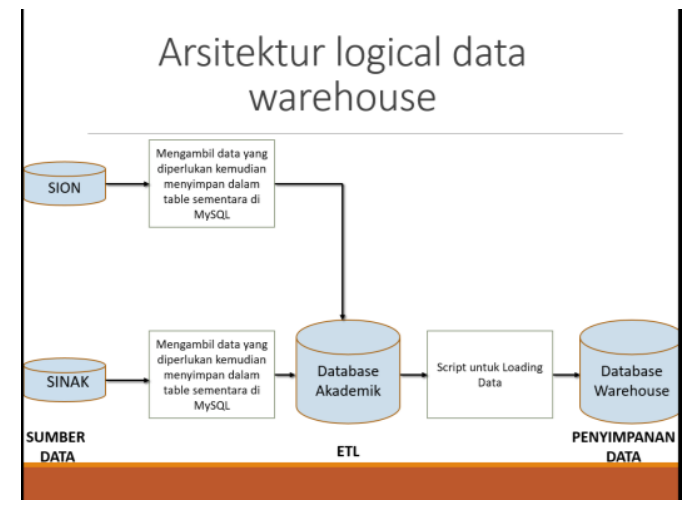

Figure 2: architecture Logical Data warehouse

B. Architecture physical Data warehouse

\section{Arsitektur fisik data warehouse}

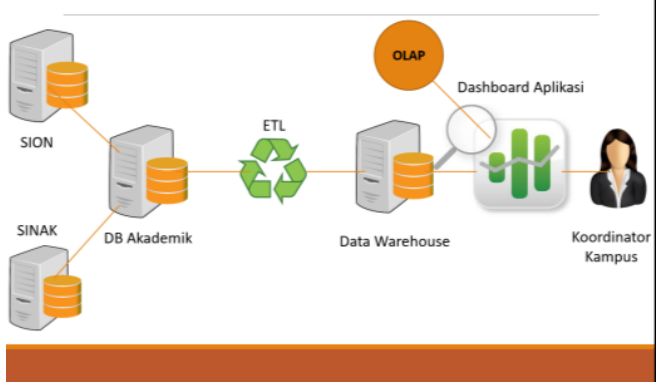

Figure 3: Architecture physical Data warehouse

\section{Planning System Requirements Data warehouse}

design stage this analysis is the mapping phase of analysis to be performed on an academic data warehouse. Based on the preparation of the needs that have been carried out, feeding the needs of data 
analysis are as shown in Table 1.

Table 1: Requirements Dashboard System

\begin{tabular}{|l|l|l|}
\hline NO & \multicolumn{1}{|c|}{ DATA ANALYSIS } & \multicolumn{1}{|c|}{ OBJECTIVES } \\
\hline 1. & $\begin{array}{l}\text { analysis value per Class } \\
\text { course participant }\end{array}$ & $\begin{array}{l}\text { Display the course } \\
\text { participants }\end{array}$ \\
\hline 2. & $\begin{array}{l}\text { Analysis Activities } \\
\text { Subject }\end{array}$ & $\begin{array}{l}\text { Displays the number of } \\
\text { meetings the subjects } \\
\text { activity }\end{array}$ \\
\hline 3. & $\begin{array}{l}\text { Analysis Questionnaire } \\
\text { results }\end{array}$ & $\begin{array}{l}\text { showing the average } \\
\text { index kuisionel results }\end{array}$ \\
\hline 4. & $\begin{array}{l}\text { Analysis Competency } \\
\text { Class }\end{array}$ & $\begin{array}{l}\text { Displays the number of } \\
\text { meetings for each grade } \\
\text { level competency plan } \\
\text { courses }\end{array}$ \\
\hline 5. & $\begin{array}{l}\text { Analysis of Grade } \\
\text { Lecturer }\end{array}$ & $\begin{array}{l}\text { Lecturer Displays the } \\
\text { average GPA }\end{array}$ \\
\hline
\end{tabular}

\section{CONCLUSION}

1. sources of data are fundamental to the development of its data warehouse to meet the Dashboard application data needs to be built.

2. The raw data in the form of documents subject study plans and instructional recordings can also be used as input data for the analysis of asset categories and sub competencies lectures.

3. Academic data contained in SION and Sinak need is the data that has been calculated properly, so that it can be used as input data for academic data warehouse.

4. By adding the will of god method can improve the user in determining the destination of the academic field of decision making.

\section{References}

[1]. Restia Rezalini PS, Mandy Anggraeni, Radityo Prasetianto Wibowo. "Design And Manufacturing Data Warehouse Supplies For Decision Support System for Academic Affairs In the Department of Information Systems, ITS, Surabaya".

[2]. Adi Supriyatna, Mochammad Wahyudi. "Designing Data Warehouse At Library Bina Sarana Informatika" 2012.

[3]. Sutedi. "Designing and Implementing Data Warehouse Data Mining at the Institute for Academic Affairs and Business Darmajaya On". 2010

[4]. Munawar. "Designing Data Warehouse For Admissions" 2013.

[5]. Hasnur Ramadan, Agus Soepriadi. "Application of Combination Model Inmon and KIMBALL On Enterprise Development and Business Intelligence Data Warehouse (EDW / BI)", 2011.

[6]. Imam Husni Al Amin. "Data Warehouse On E-Learning" 2010.

(p-issn: 2579-5988, e-issn: 2579-597X)
[7]. Paulraj, Ponniah. "Data Warehousing Fundamental" 2001

[8]. Wahib, Aminul. “Analisa Data Akademik Berbasis Data Warehouse dengan DSS Yang Merekomendasikan Beasiswa Bagi Mahasiswa Jurusan Teknik Informasitka Politeknik Elektronika Negeri Surabaya” 2009.

[9]. Bouman, Ronald \& Dongen, Jos van. "Pentaho Solutions Business Intelligence and Data Warehousing with pentaho and MySQL" 2010.

[10]. Jeffey A. Hoffer, Mary B Prescott, \& Fred R.McFadden. "Modern Database Management". 2005

[11]. Rainardi, Vincent. "Building a Data Warehouse with Examples in SQL Server" 2008.

[12]. Efraim Turban, Jay E.Aronson, Ting-Peng Liang. "Decision Support Systems and Intelligent Systems", 2005.

[13]. Kennet C, Jane P. "Management Information Systems, Managing The Digital Firm”, 2004.

[14]. Raghu Ramakrishnan, Johannes Gehrke. "Database Management Systems", 2003.

[15]. Jeffrey A. Hoffer, Mary B Prescott, \& Fred R. Mc Fadden. "Modern Database Management Sevent Edition Prentice Hall". 2005 